and are there pathologies that scramble it?

But you don't have to contemplate enigmatic research questions to enjoy this book. Some essays are touching indeed. In 'Why life speeds up as you get older' (which gives the book its title), Draaisma cites a letter from a patient suffering from Alzheimer's disease who no longer remembers that her husband died eight years ago, and keeps writing him heartbreaking letters. Reading this left me not only with a semantic trace, but also with an episodic one. I suspect it will do the same to other readers as well.

Yadin Dudai is in the Department of

Neurobiolology, Weizmann Institute of Science, Rehovot 76100, Israel.

\section{Down to business}

\section{University, Inc: The Corporate Corruption of Higher Education by Jennifer Washburn \\ Basic Books: 2005. 384 pp. \$26, £19.99}

\section{Graham Richards}

Money corrupts. It was ever thus, but the thesis of this important book is that the universities' current dependency on industrial links has reached a moral crisis point. Academic freedom, the book contends, has been severely compromised, with damage being done to the public and to the values of higher-education institutions. Here I must declare a conflict of interest, as I have been closely involved in creating spin-off companies and in a multimillion-pound deal to finance a state-of-the-art laboratory. Despite my possible bias in favour of technology transfer, University Inc. shakes one's confidence and provokes the realization that some things may have to change.

It is a scholarly book, with almost 700 references and footnotes. However, the author, journalist Jennifer Washburn, cannot resist irritating portraits of many of the major players, for example describing Clark Kerr as "a balding man with bushy white eyebrows and alert blue eyes". It is written exclusively from the United States point of view, where for a long time there has been tension between a utilitarian view of universities, as expressed by Thomas Jefferson, who favoured "a useful American education", and the élitist attitude more prevalent in older European-style institutions, such as Harvard University. Nevertheless, as colleges across the world try to emulate the success of their top US competitors, they are faced with the same dilemmas, encouraged by governments espousing the 'knowledge economy'. Commercial values have been stamped on academic life.

Universities routinely run patenting and licensing operations, invest in risky startups, run their own industrial parks and

\section{Exhibition}

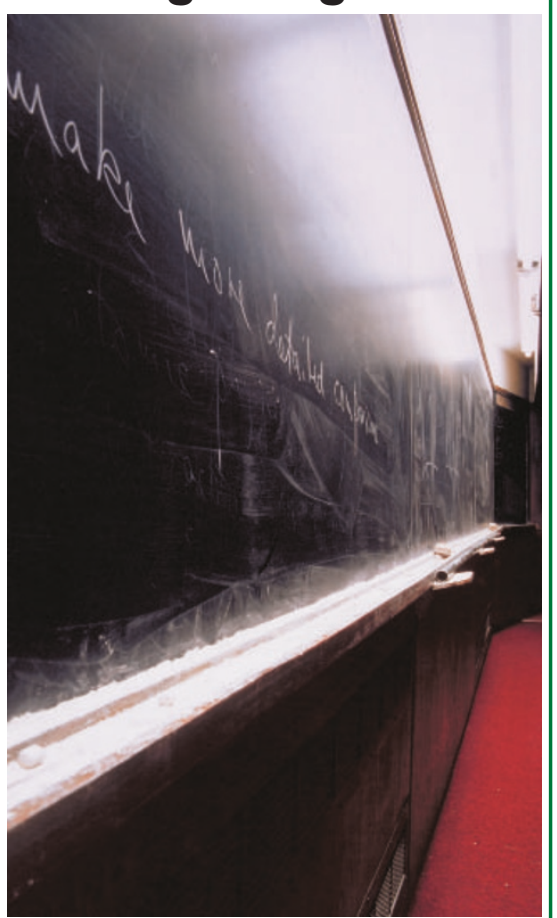

Naglaa Walker, herself a trained physicist, explores the exact world of science from an inexact, intuitive perspective. This photograph captures the image of a passing thought chalked on a blackboard, which is as temporary as the writer wants it to be. It is one of a series in her exhibition On Physics, which runs until 7 May at the Hug Gallery for International Photography in Amsterdam.

venture-capital funds, and encourage their faculty to set up companies. But sponsorship brings the risk of ceding control, changing the direction of research and altering the priorities of universities, even to the extent of marginalizing the humanities.

Washburn examines in detail several well-publicized case histories, including an agreement between the University of California, Berkeley, and Novartis. The company gave the university $\$ 25$ million over five years for first right to negotiate licences on roughly one-third of the discoveries in the Department of Plant and Microbial Biology. Washburn also takes a rather jaundiced view of the Institute for Bioengineering, Biotechnology and Quantitative Biomedicine (QB3) at Mission Bay, San Francisco - a cooperative effort among three campuses of the University of California and private industry.

The rise of the market-model university dates from the discovery of recombinant DNA technology by Stanley Cohen and Herbert Boyer in 1973 and its subsequent patenting. Washburn provides detailed scrutiny of what she considers the villain of the piece, the Bayh-Dole Act, signed into law by President Carter in December 1980. The bill seems to have been crafted originally to grant automatic patent rights to just universities and small businesses. It contained safeguards, such as a 'march-in' provision to enable the federal government to terminate licences, and time limits on exclusivity, but few of these survived to the final legislation. Major corporations did not lobby to oppose the act, which the Reagan administration soon extended to include them.

Since the 1980s, the desire to maximize entrepreneurial gains has grown, and they have become significant sources of university funds. DuPont gave $\$ 6$ million to Harvard, and the German chemical company Hoechst provided $\$ 50$ million for Massachusetts General Hospital — this was targeted money with expected tangible returns in terms of exclusive rights.

The most worrying questions, though, relate to clinical trials. Washburn recounts in detail the problems faced by James Kahn of the University of California, San Francisco, with a trial of the AIDS drug Remune, which was funded by the Immune Response Corporation, and the genetic-engineering trial at the University of Pennsylvania that resulted in the death of Jesse Gelsinger. No one can read these and other case histories in the book without considerable disquiet.

But what is to be done? Pandora's box is already open. We cannot turn back the clock and return to a community of lone scholars, each seeking truth. Modern research in most areas needs massive funding - more than even the richest governments can afford. It is totally unrealistic to place walls between academic institutions and private industry. Universities can, and must, contribute to scientific and technological innovation for wealth creation without compromising their core scholarly principles, academic freedom or essential autonomy. In my opinion, this is becoming even more important as industrial innovations are increasingly the product of small companies, often spun out from universities, while larger corporations concentrate on marketing and selling.

Washburn suggests four fundamental changes. First, she calls for the creation of an independent, third-party licensing body that would assume control over technologytransfer activities in the United States, perhaps allowing some of the more successful campuses to opt out. Second, she has the Bayh-Dole act firmly in her sights, and would have Congress revisit and revise it. In particular, she would change the language so exclusive licensing was the exception and not the norm. Furthermore, she wants the federal government to be able to intercede more easily to provide access to all taxpayer-funded research. The third reform, which would certainly be welcomed in most academic departments, would be to introduce strict conflict-of-interest laws, although the problems in laboratories at the US National Institutes of Health shows how even this might 
cause tensions. Finally, she would create a new federal agency to administer and monitor industry-sponsored clinical trials. The fact that there are stirrings in all of these directions suggests that she may well have identified the sensitive areas.

For the world outside the United States particularly southeast Asia, where research is more related to health and wealth creation there are lessons to be learned from this book. The financial imperatives need to be kept in check to avoid serious damage, not just to science but to people's lives.

Graham Richards is chairman of chemistry at the University of Oxford, and chairman of the intellectual-property company IP2IPO Group.

\section{Politics and history through the mill}

\section{Maize and Grace: Africa's Encounter with a New World Crop 1500-2000}

by James C. McCann

Harvard University Press: 2005. 320 pp. $\$ 27.95, £ 18.95$, €25.80

\section{Robert Tripp}

Political, social and economic change has often been associated with the introduction and adaptation of new crop species. Maize and Grace shows how a New World crop contributed to the emergence of modernday Africa. Some parts of Africa now have higher maize consumption per capita than Mexico and Guatemala, where the crop originated. Indeed in many African countries, maize production and supply is an issue that attracts an exceptional level of political attention.

It is unlikely that 500 years of history in a continent of diverse cultures and environments could produce a single, consistent narrative of crop adaptation, so James McCann has wisely chosen instead to provide brief glimpses of several important episodes in Africa's engagement with maize. Historical data on the crop's arrival in West Africa and its subsequent use are unfortunately very scanty, and much of the discussion focuses on what linguistic evidence might tell us. More detail is available to discuss the expansion of maize growing (and the priorities of maize breeding) in eastern and southern Africa in the past two centuries. There are also chapters exploring the response of the scientific community to a brief outbreak of rust disease in West Africa in the 1950s, and about a hypothesis linking the recent expansion of maize growing in northwest Ethiopia to a malaria epidemic.

McCann is fairly even-handed in his analysis, avoiding the temptation to cast maize as either hero or villain in the evolution of

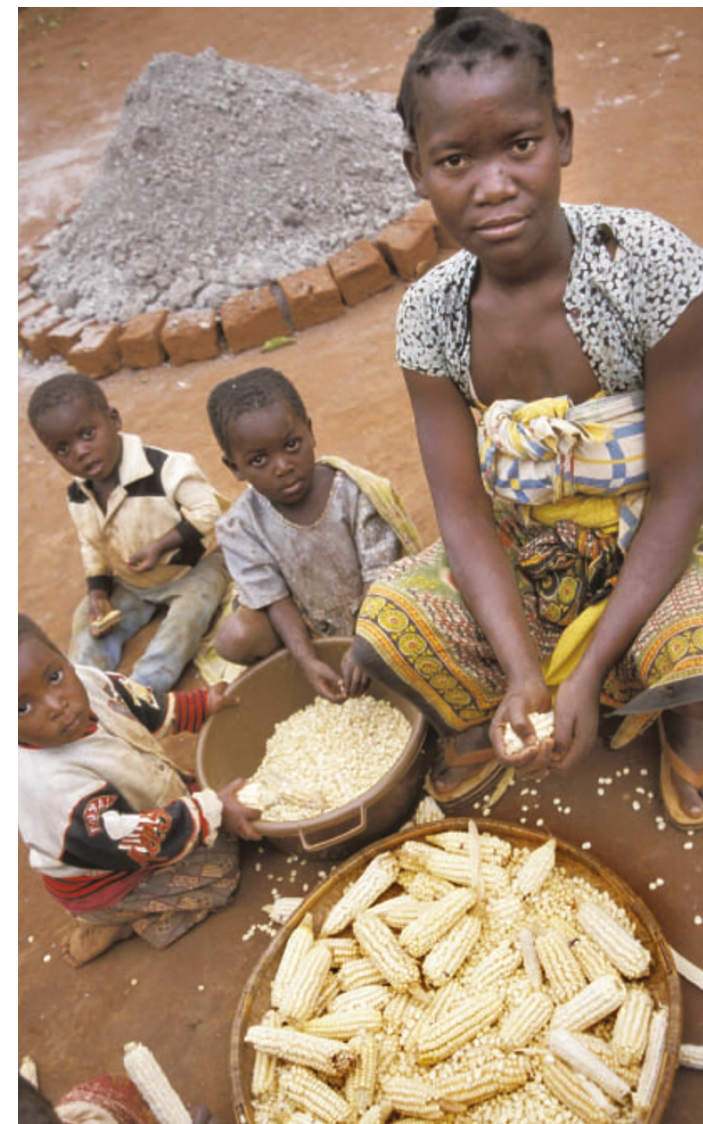

Same again? A foreign crop has become Africa's staple.

enduring themes in agricultural history. Development specialists worry about whether Africa's farmers can adapt to increasingly rigid standards for export agriculture. But they may be unaware that the dominance of white maize in southern and eastern Africa owes much to the fact that colonial maize farmers in the early twentieth century planted it to take advantage of export opportunities to Britain, where white starch was in demand. Similarly, current debates about agricultural subsidies in rich countries can be seen in the light of carefully constructed colonial policies that favoured European farmers in Africa.

Investment in agricultural research led to the highly productive single-cross maize hybrid SR52, which helped to support the economy of the breakaway Rhodesian regime. But McCann misses the opportunity to explore how the succeeding Zimbabwe government's devotion to hybrid maize led it to prohibit the sale of openpollinated varieties.

Although McCann focuses on Africa, he provides some fascinating comparisons and links with

African agricultural systems. The peasants in this tale are pragmatists, not traditionalists; they are engaged with states and markets, seeking secure livelihoods and ways of coping under different political regimes. The agronomic advantages of maize provided African farmers with a productive earlymaturing crop, allowed them to harvest and consume the green ears, and freed them from the bird-scaring required with native cereals. Its economic advantages included wide market demand and suitability for industrial milling techniques.

Maize farming provided opportunities for, and was in turn moulded by, the development of native kingdoms, colonial administrations and independent states in Africa. Crops can, of course, make significant contributions to political regimes without being transferred to new environments: the Incas imposed maize agriculture in their dominion to demonstrate their political control and to feed their armies. And Africa's crops have had an impact in the New World: in the late twentieth century, traditional maizegrowing areas in central Mexico were transformed into sorghum fields as the economics of crop production and government policies stimulated the search for alternative crops.

Rather than describing sweeping historical currents, the book offers the reader a series of vignettes that provide opportunities to appreciate the paradoxes of maize development policy and to contemplate some southern Europe. During the eighteenth and nineteenth centuries, while maize and cassava were contributing to the growth and political dominance of the kingdom of Asante in West Africa, maize was helping to transform the agriculture of the Venetian republic. And although, as he argues, maize cropping patterns in Ethiopia may be partly responsible for the contemporary spread of malaria, farmers in the Balkans adopted maize to keep them away from the malariaridden lowlands. We can mourn the loss of maize diversity in the field and on the table, reflected both in Africans' development of a preference for white maize and in Italians' abandonment of their polenta made from red flint varieties.

The book usefully juxtaposes maize's multiple trajectories in the hands of African farmers with the political and economic forces that increasingly mandate uniform cropping patterns, and with market requirements. These forces are not, of course, unique either to maize or to Africa. McCann fails to answer the question of whether maize can indeed be Africa's "saving grace", and the concluding chapter only touches on the larger questions now facing Africa's agriculture. But the book's nicely drawn examples provide opportunities for reflection as these issues are debated.

Robert Tripp is at the Overseas Development Institute, 111 Westminster Bridge Road,

London SE1 7JD, UK. 